\title{
Pengaruh Atribut Produk, Kualitas Produk dan Promosi, Terhadap Keputusan Pembelian Mobil Merek Honda Di Kota Medan
}

\author{
Bunga Aditi $^{1 *}$ H. M. Hermansyur ${ }^{2}$ \\ Fakultas Ekonomi dan Bisnis, Universitas Harapan \\ Jalan Imam Bonjol No. 3 Medan, Indonesia \\ Email: bunga.aditi16@gmail.com
}

\begin{tabular}{c}
\hline Artikel Info \\
\hline Submited: \\
2 Maret 2018 \\
Revised: \\
18 April 2018, \\
Accepted: \\
21 April 2018 \\
\hline
\end{tabular}

\begin{abstract}
ABSTRAK
Penelitian ini bertujuan untuk mengetahui dan menjelaskan pengaruh atribut produk, kualitas produk, dan promosi secara partial dan simultan terhadap keputusan pembelian. Jenis penelitian yang digunakan adalah explanatory research dengan pendekatan kuantitatif. Pengambilan sampel mengunakan Non-Probability Sampling yaitu sampling jenuh sebanyak 100 responden dengan menggunakan teknik analisis Regresi Linier berganda. Hasil penelitian menunjukkan bahwa variabel Atribut produk, kualitas produk, promosi secara parsial berpengaruh signifikan terhadap keputusan pembelian. Hasil secara simultan menunjukkan bahwa variabel Atribut produk, kualitas produk dan promosi berpengaruh signifikan terhadap keputusan pembelian. Oleh karena itu, sebaiknya perusahaan dapat menginformasikan mobil merek Honda dengan lebih baik mengenai Atribut produk, kualitas produk dan harga melalui para salesnya, agar mereka lebih paham dalam memasarkan produknya.
\end{abstract}

Kata Kunci : Atribut Produk, Kualitas Produk, Keputusan Pembelian, Promosi,

Influence of Product Attributes, Product Quality, and Promotion on the Purchase Decision of Honda Brand Car in Medan City

\begin{abstract}
This study aims to identify and explain the influence of product attributes, product quality, and partial and simultaneous promotion on purchasing decisions. This type of research is explanatory research with a quantitative approach. Sampling using NonProbability Sampling is the saturated sampling of 100 respondents using multiple linear regression analysis techniques. The results showed that the variable product attributes, product quality, promotion of partially significant effect on purchasing decisions. The results of the simultaneous shows that the variable product attributes, product quality, and promotion significantly influence purchasing decisions. Therefore, the company should be able to inform the Honda brand car with a better understanding of product attributes, product quality, and price through the sales conversations, so that they are understood in marketing their products.
\end{abstract}

Kata Kunci: Product attributes, product quality, promotion, purchase decision

\footnotetext{
How to Cite:

Aditi, B., \& Hermansyur, H. M. (2018). Pengaruh Atribut Produk, Kualitas Produk Dan Promosi, Terhadap Keputusan Pembelian Mobil Merek Honda Di Kota Medan. Jurnal Ilmiah Manajemen dan Bisnis, 19(1),64-72. https://doi.org/10.30596/jimb.v19i1.1743.
} 


\section{PENDAHULUAN}

Persaingan produk yang semakin ketat dengan masuknya produk-produk inovatif ke pasaran yang mana terdapat kondisi pasar yang jenuh untuk produk-produk, di sisi lain usaha untuk mengelola loyalitas konsumen menjadi tantangan yang tidak mudah, konsumen memiliki beraneka ragam kebutuhan dan keinginan yang dapat dipenuhi dengan mengkonsumsi produk tertentu. Aditi, (2017) menyatakan atribut produk berpengaruh terhadap minat beli konsumen. Begitu juga dengan penelitian yang dilaku kan oleh Widiyatno, (2012) yang menyata kan bahwa atribut produk berpengaruh terhadap keputusan pembelian. Hasil penelitian yang juga dilakukan oleh Sindi, (2013) juga menyatakan atribut produk, harga dan strategi promosi berpengaruh terhadap keputusan pembelian.

Pada saat ini konsumen di kota Medan biasanya memilih prioritas utama dan berusaha mencari dan membeli produk yang dinilainya lebih baik dan memberikan manfaat. Konsumen biasanya membuat skala prioritas dan berusaha mencari dan membeli produk yang dinilai paling sesuai dan memuaskan, meningkatnya pembelian konsumen akan mampu meningkatkan daya saing perusahaan tersebut terhadap perusahaan pesaing. Suatu produk yang ditawarkan ke konsumen oleh perusahaan akan bertahan di pasaran jika atribut dari produk tersebut diterima. Menurut Kotler dan Keller, (2009) keputusan pembelian adalah keputusan konsumen mengenai preferensi atas merek -merek yang ada di dalam kumpulan pilihan brand image yang dimiliki perusahaan, atribut produk dengan kualitas yang baik dan harga produk yang tepat, hal ini kan mempengaruhi konsumen untuk keputusan pembelian. Atribut produk (merek, harga, kualitas, dan desain) secara parsial dan simultan berpengaruh signifikan terhadap proses keputusan pembelian konsumen dengan variabel merek yang paling dominan (Khoirotunnisa dan Titis,
2016). Hal ini bertolak belakang dengan penelitian yang dilakukan oleh Onsu et al., (2015) atribut produk tidak berpengaruh terhadap keputusan pembelian sepeda motor di Dealer Yamaha Ranotana.

Setiap produk yang sudah memasuki pasar internasional pasti memiliki ciri khas dan kualitas produk masing-masing. Menu rut penelitian yang dilakukan oleh Anis et al., (2015) menyatakan bahwa kualitas produk berpengaruh positif terhadap variabel citra merek Internasional dan keputusan pembelian. Sedangkan menurut Kotler dan Armstrong, (2008), kualitas produk (product quality) adalah karakteristik produk yang bergantung pada kemampuannya untuk memuaskan kebutuhan pelanggan yang dinyatakan atau diimplementasikan. Kemudian Heizer dan Render, (2012) kualitas produk adalah "''keseluruhan fitur dan karakteristik produk yang mampu memuaskan kebutuhan yang terlihat maupun tidak terlihat"". Jadi hanya perusahaan dengan kualitas produk yang paling baik yang akan tumbuh dengan pesat, dan dalam jangka panjang perusahaan tersebut akan berhasil dan lebih unggul dari perusahaan yang lain. Hasil penelitian juga dilakukan oleh S Kudo, (2013) menyatakan bahwa menunjukkan bahwa harga, kualitas produk dan kualitas pelayanan secara simultan maupun parsial berpengaruh signifikan terhadap keputusan pembelian.

Modi et al., (2012) menyatakan bahwa skema promosi memiliki implikasi besar pada keputusan pembelian. Pemasar dapat menggunakan kombinasi skema promosi yang relevan sebagai alat yang efektif untuk menjual produk mereka. Penelitian ini bertolak belakang dengan yang dilakukan oleh Rares dan Jorie, (2015) yang menyatakan bahwa promosi, lokasi dan citra merek tidak berpengaruh signifkan terhadap keputusan pembelian. Begitu juga penelitian yang dilakukan oleh Zulkarnaim, (2015) yang mengatakan bahwa Promosi berpengaruh terhadap keputusan pembelian 
konsumen. Begitu juga penelitian yang dilakukan oleh Anuraga, (2016) yang mengungkapkan bahwa promosi berpengaruh terhadap keputusan pembelian ulang.

Kotler dan Amstrong, (2010) mengatakan keputusan pembelian merupakan sebuah proses pendekatan penyelesaian masalah yang terdiri dari pengenalan masalah, mencari informasi, beberapa penilaian alternative, membuat keputusan membeli, dan perilaku setelah membeli yang dilalui oleh konsumen. Faktor-faktor lain yang mempengaruhi keputusan pembelian, antara lain harga, promosi dan produk. Atribut produk merupakan karakteristik dari produk atau jasa yang menghasilkan kemampuan untuk memuaskan yang dinyatakan atau tersirat pada kebutuhan konsumen (Kotler dan Armstrong, 2007). Kemduian Kotler dan Amstrong, (2008) mengatakan kualitas produk merupa- kan karakteristik produk atau jasa yang tergantung pada kemampuanya untuk memuaskan kebutuhan pelanggan yang dinyatakan atau diimplikasikan. Kemudian Promosi. Tjiptono (2008) mengatakan promosi dapat didefenisikan sebagai suatu bentuk komunikasi pemasaran, komunikasi pemasaran adalah aktivitas pemasaran yang berusaha menyebarkan informasi, mempengaruhi/membujuk/mengingatkan pasar sasaran atas perusahaan dan produknya agar bersedia menerima, membeli, dan loyal pada produk yang ditawarkan perusahaan yang bersangkutan.

Untuk memperjelas hubungan antara Atribut produk, kualitas produk dan promosi dengan keputusan pembelian dapat ditunjukkan dengan skema sebagai berikut:

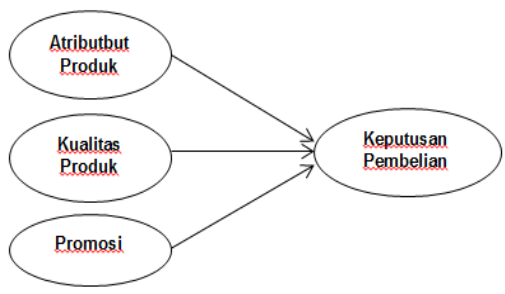

Gambar 1. Model Penelitian
Berdasarkan teori pendapat dari referensi yang telah dikemukan, maka hipotesis pada penelitian adalah H1: Ada pengaruh antara Atribut produk terhadap keputusan pembelian merek Honda di kota Medan. H2: Ada pengaruh antara Kualitas produk terhadap keputusan pembelian merek Honda di kota Medan. H3: Ada pengaruh antara promosi terhadap keputusan pembelian merek Honda di kota Medan. $\mathrm{H}_{4}$ : Ada pengaruh antara atribut produk, Kualitas produk dan promosi terhadap keputusan pembelian merek Honda dikota Medan

\section{METODE}

Penelitian ini menggunakan pendekatan kuantitatif dengan menggunakan sampel minimal 100 responden untuk memberikan hasil yang lebih baik., sampel dalam penelitian ini sesuai dengan teori Hair, et al., (2007) yaitu 100 orang. Pengambilan sampel mengunakan Non-Probability Sampling yaitu sampling jenuh dimana semua anggota populasi dijadikan sampel (Sugiyono, 2010). Teknik Pengumpulan Data yang digunakan adalah pengamatan (observasi), wawancara, kuisioner. Untuk mengukur keputusan pembelian pada penelitian ini menggunakan kuisioner dengan skala liker, indikator yang digunakan pada penelitian ini untuk Keputusan Pembelian yaitu pengenalan kebutuhan, pencarian alternatif informasi, penilaian berbagai macam informasi yang terkumpul, keputusan membeli, evaluasi Setelah pembelian, sedangkan Atribut Produk menggunakan indikator, harga produk, fitur produk, desain produk, kualitas produk, gaya produk, kemudian untuk indikator Kualitas Produk yaitu kemudahan penggunaan, daya tahan, kejelasan fungsi, keragaman produk, dan untuk Promosi menggunakan indikator survei perilaku pelanggan, survei perilaku pesaing, survei kondisi lingkungan pasar, penjualan langsung, hubungan masyarakat. Setelah 


\section{Published April 2018 \\ JURNAL ILMIAH MANAJEMEN dan BISNIS \\ ISSN 1693-7619 (print) | ISSN 2580-4170 (online), http://jurnal.umsu.ac.id/index.php/mbisnis}

dilakukan penyebaran kuisioner kepada 100 responden, sebelum dilakukan analisis data terlebih dahulu akan diuji validitas dari indikator kuisioner tersebut, uji validitas yang digunakan menggunakan korelasi product moment, dimana jika $r_{\text {hitung }}>r_{\text {tabel }}$, item pertanyaan dikatakan valid. Hasil uji validitas yang diperoleh bahwa $\mathrm{r}$ hitung > 0.1966 (rtabel), maka dapat kuisioner dinyatakan valid. Kemduian untuk mendapatkan tingkat ketepatan instrument yang digunakan, dilakukan uji reliabilitas, Pengujian dilakukan dengan digunakan adalah teknik Cronbach Alpha. hasil uji reliablitas yang diperoleh menunjukkan nilai Cronbach Alpha tiap variabel > 0,70 (Ghozali, 2011), maka variabel penelitian ini adalah reliabel dan dapat dilanjutkan dengan uji asusmsi klasik. Teknik analisa data yang digunakan adalah Analisis Regresi Linear Berganda, dengan persamaan $\mathrm{Y}=\mathrm{a}+\mathrm{b} 1 \mathrm{X} 1+\mathrm{b} 2 \mathrm{X} 2+\mathrm{b} 3 \mathrm{X} 3+\mathrm{e}$.

\section{HASIL}

Hasil uji normalitas dalam penelitian ini membuktikan bahwa model regresi telah memenuhi asumsi yang telah dikemukakan sebelumnya, dikatakan memenuhi asusmsi normalitas jika data menyebar disekitar garis diagonal dan mengikti ara garis diagonal maka model regresi memenuhi asumsi normalitas. Hasil Uji Multikolinieritas. Multikolinearitas digunakan untuk menguji apakah pada model regresi ditemukan adanya korelasi yang kuat antar variabel independen. Ketiga Variabel Atribut produk memperoeh nilai VIF 1,211, variabel kualitas kerja memperoleh nilai VIF 1,321, dan promosi memperoleh nilai VIF 1,325, dalam batas teloransi yang telah ditentukan. Dalam mengambil keputusan untuk melihat nilai telorance. Jika nilai VIF dalam batas teloreance yang telah ditentukan $<5$ atau tidak melebihi 5 , nilai telorance $>0,1$ sehingga tidak terjadi multikolinearitas dalam variabel independen penelitian ini atau tidak saling berkorelasi sesama variabe bebasnya (Hines dan Montgommery, 1990).

Berdasarkan analisis data yang telah dilakukan, maka dapat diketahui bahwa model regeresi menggunakan analisis linear berganda ini dilihat dari Tabel .

Tabel 1. Hasil Analisis Regresi Berganda

\begin{tabular}{llrrrrr}
\hline \multicolumn{7}{c}{ Unstandardized Coefficients } \\
Model & B & $\begin{array}{c}\text { Standardized } \\
\text { Coefficients } \\
\text { Beta }\end{array}$ & \multicolumn{1}{c}{ t } & Sig. \\
\hline $1 \quad$ (Constant) &, 724 &, 852 &, 176 &, 850 &, 398 \\
& Atribut Produk &, 198 &, 093 &, 131 & 0,036 \\
& Kualitas Produk &, 409 &, 121 &, 396 & 3,385 & 0,001 \\
& Promosi &, 321 &, 091 &, 338 & 3,505 & 0,001 \\
\hline
\end{tabular}

a. Dependent Variable: Keputusan pembelian

Tabel 1 menunjukkan persamaan regresi linear berganda pada penelitian ini yaitu $\mathrm{Y}=0,724+0.198 \mathrm{X}_{1}+0.409 \mathrm{X}_{2}+$ $0.321 \mathrm{X}_{3}+\mathrm{e}$, dimana Nilai konstanta regresi sebesar 0.724 artinya jika nilai Atribut produk, kualitas produk dan promosi $=0$, maka keputusan pembelian akan meningkat sebesar 0.724. Koefisien regresi $\mathrm{X}_{1}$ untuk variabel Atribut Produk bernilai positif 0.198 artinya pengaruh Atribut Produk sangat berpengaruh dalam meningkatkan keputusan pembelian, Atribut produk dapat memberikan dampak positif terhadap keputusan pembelian. Koefisien regresi $\mathrm{X}_{2}$ untuk variabel Kualitas produk bernilai positif 0.409 artinya kualitas produk sangat berpengaruh dalam meningkatkan keputusan pembelian, Kualitas produk dapat memberikan dampak positif terhadap keputusan pembelian. Koefisien regresi $\mathrm{X}_{3}$ untuk 


\section{Published April 2018 \\ JURNAL ILMIAH MANAJEMEN dan BISNIS \\ ISSN 1693-7619 (print) | ISSN 2580-4170 (online), http://jurnal.umsu.ac.id/index.php/mbisnis}

variabel promosi bernilai positif 0.321 artinya pengaruh promosi sangat berpengaruh dalam meningkatkan keputusan pembelian, promosi dapat memberikan dam pak positif terhadap keputusan pembelian.

Pada Tabel 1 hasil uji $t$ memperlihatkan nilai $t_{\text {hitung }}$ Atribut produk (X1) sebesar 2,131 > $t_{\text {tabel }}$ sebesar 1,660 dengan probilitas nilai sig 0,036 $<0.05$, maka variabel Atribut produk (x1) berpengaruh positif dan signifikan terhadap variabel keputusan pembelian. Nilai $t_{\text {hitung }}$ kualitas produk (X2) sebesar 3,385 $>\mathrm{t}_{\text {tabel }}$ sebesar 1,660, dengan probilitas sig $0,001<$ 0,05, maka kualitas produk berpengaruh positif dan signifikan terhadap variabel keputusan pembelian, selanjutnya pada variabel promosi (X3) adalah sebesar 3,505 $>t_{\text {tabel }}$ sebesar 1,660 dengan probilitas sig $0,001<0,05$, maka variabel promosi ber pengaruh positif dan signifikan terhadap variabel keputusan pembelian. Hasil Uji secara simultan dapat dilihat pada Tabel 2.

Tabel 2. Hasil uji F

\begin{tabular}{|c|c|c|c|c|c|c|}
\hline & & $\begin{array}{c}\text { Sum of } \\
\text { Squares }\end{array}$ & df & Mean Square & $\mathbf{F}$ & Sig \\
\hline \multirow[t]{3}{*}{1} & Regression & 209,509 & 3 & 69,836 & 66,949 &, $000^{6}$ \\
\hline & Residual & 101,184 & 97 & 1,043 & & \\
\hline & Total & 310,693 & 100 & & & \\
\hline
\end{tabular}

a.DependentVariable: Keputusan Pembelian

b.Predictors: (Constant), Promosi, Atribut produk, Kualitas produk

Hasil Uji F pada Tabel 2 memperlihat kan nilai $\mathrm{F}$ hitung sebesar 66,949> $\mathrm{F}_{\text {tabel }}$ $(2,70)$, dengan probilitas nilai sig sebesar $0.000<0.05$, dengan demikian dapat disimpulkan bahwa Atribut produk, kualitas produk, dan promosi secara bersama-sama berpengaruh terhadap keputusan pembelian.
Untuk dapat mengetahui besarnya koefisien determinasi $\left(\mathrm{R}^{2}\right)$ Atribut produk, kualitas produk, dan promosi menjelaskan keputusan pembelian dapat dilihat pada Tabel 3.

Tabel 3. Hasil Koefisien Determinasi

\begin{tabular}{lcccc}
\hline Model & $\mathrm{R}$ & $\mathrm{R}$ Square & $\begin{array}{c}\text { Adjusted } \mathrm{R} \\
\text { Square }\end{array}$ & $\begin{array}{c}\text { Std. Error of } \\
\text { the Estimate }\end{array}$ \\
\hline 1 &, 821 &, 674 &, 664 & 1,021 \\
\hline $\begin{array}{l}\text { a. Predictors: (Constant, Promosi, Atribut produk, Kualitas produk } \\
\text { b. DependentVariable: Keputusan pembelian }\end{array}$
\end{tabular}

Tabel 3, diketahui bahwa nilai $\mathrm{R}$ square sebesar 0.674 atau sama dengan $67.4 \%$ artinya bahwa Atribut produk, Kualitas produk, dan promosi mampu menjelaskan keputusan pembelian adalah sebesar $67.4 \%$ sisanya sebesar $32.6 \%$ dijelaskan oleh variabel lain yang tidak dimasukkan dalam model penelitian ini.
PEMBAHASAN

Pengaruh Atribut Produk Terhadap Keputusan Pembelian Merek Honda Di Kota Medan

Berdasarkan analisis secara parsial bahwa atribut produk memiliki pengaruh positif terhadap keputusan pembelian merek Honda di kota medan. Hal ini dapat dibuktikan dari hasil uji parsial dimana nilai signifikansinya untuk variabel atribut produk ( 0,036) lebih kecil dari batasan 
signifikan sebesar 0,05 atau thitung sebesar 2,131 lebih besar dari t tabel sebesar 1,660 (n-4=100-4=96), dengan demikian secara parsial bahwa variabel atribut produk berpengaruh positif terhadap keputusan pembelian merek Honda di kota Medan. Hasil penelitian sesuai dengan penelitian yang dilakukan oleh Subagio, (2015); Akpoyomare et al., (2012) yang menyata kan bahwa atribut produk berpengaruh postif dan signifikan terhadap keputusan pembelian. Keputusan pembelian konsumen dapat dilihat sebagai suatu proses di mana konsumen mengevaluasi produk alternatif pada kekuatan berbagai atribut dan atas dasar pemasar yang membedakan dan mengatur merek mereka terpisah dari persaingan. Implikasi manajerial dalam penelitian yang dapat dilakukan manajemen PT Honda harus lebih memperhatikan atribut produk yang merupakan cara potensial untuk mengatasi persaingan yang semakin kuat dan mampu mendiferensiasikan serta memposisikan produk dan jasa perusahaan. Nilai $\mathrm{R}$ square untuk atribut produk sebesar 0.198 atau 19,8\%. Hasil penelitian ini membuktikan atribut produk berpengaruh terhadap keputusan pembelian seperti fitur produk, desain produk dan label produk, dan gaya produk sesuai dengan selera konsumen, menyediakan berbagai suku cadang yang diperlukan oleh konsumen Sedangkan atribut produk lain yang tidak diteliti dalam penelitian ini seperti jaminan (garansi), pelayanan purna jual.

\section{Pengaruh Kualitas Produk Terhadap Keputusan Pembelian Merek Honda Di Kota Medan}

Berdasarkan analisis secara parsial bahwa kualitas produk memiliki pengaruh positif terhadap keputusan pembelian merek Honda di kota medan. Hal ini dapat dibuktikan dari hasil uji parsial dimana nilai signifikansinya untuk variabel kualitas produk $(0,001)$ lebih kecil dari batasan signifikan sebesar 0,05 atau thitung sebesar 3,385 lebih besar dari t tabel sebesar 1,660 ( $\mathrm{n}-4=100-4=96)$. Berdasarkan hasil yang diperoleh maka ditolak Ho dan menerima Ha. Dengan demikian secara parsial bahwa variabel kualitas produk berpengaruh positif terhadap kepetusan pembelian merek Honda di kota Medan. Hasil penelitian sesuai dengan penelitian yang dilakukan Priyono, Iyon (2017); Lubis, (2015) menyatakan kualitas mempe-ngaruhi keputusan pembelian. Implikasi manajerial yang dapat diterapkan oleh perusahaan dari hasil penelitian ini bahwa perusahaan harus terus melakukan pengem-bangan dan selalu tetap menjaga nama baik perusahaan dengan lebih meningkatkan kualitas produk dalam bersaing dengan perusahaan mobil lainnya. Kualitas produk akan membuat konsumen lebih percaya dan tetap melakukan pembelian. seperti mencip-takan berbagai iptek di mobil sehingga mempermudah konsumen menggunakan mobil tersebut, memperhatikan daya tahan mobil Honda tersebut. Nila $\mathrm{R}$ square untuk kualitas produk berpengaruh terhadap keputusan pembelian sebesar 0.409 atau 40,9\%. Hasil penelitian menyatakan bahwa kualitas produk berpengaruh terhadap keputusan pembelian seperti kemudahan penggunaan, daya tahan, keragaman produk .Sedangkan variabel lain yang belum diteliti seperti kejelasan fungsi.

\section{Pengaruh Promosi Terhadap Keputusan Pembelian Merek Honda Di Kota Medan}

Berdasarkan analisis secara parsial bahwa promosi memiliki pengaruh positif terhadap keputusan pembelian merek Honda di kota medan. Hal ini dapat dibuktikan dari hasil uji parsial dimana nilai signifikansinya untuk variabel promosi $(0,001)$ lebih kecil dari batasan signifikan sebesar 0,05 atau $t_{\text {hitung }}$ sebesar 3,505 lebih besar dari $t_{\text {tabel }}$ sebesar 1,660 (n-4=100-4=96). Berdasarkan hasil yang diperoleh maka ditolak Ho dan menerima Ha. Dengan demikian secara 


\section{Published April 2018 \\ JURNAL ILMIAH MANAJEMEN dan BISNIS \\ ISSN 1693-7619 (print) | ISSN 2580-4170 (online), http://jurnal.umsu.ac.id/index.php/mbisnis}

parsial bahwa variabel promosi berpengaruh positif terhadap keputusan pembelian merek Honda di kota Medan. Hasil penelitian sesuai dengan penelitian yang dilakukan oleh Walukow, et al., (2014); Aditi dan Hermansyur, (2017) yang menunjukkan bahwa kualitas, produk, harga, promosi, lokasi berpengaruh positif terhadap keputusaan pembelian konsumen. Implikasi manajerial yang dapat digunakan oleh perusahaan lebih sering melakukan promosi penjualan seperti event-event Expo atau pameran, mensponsori suatu kegiatan dan lain-lain, hal ini diperkuat oleh penelitian Nasution, et al., (2017) bahwa Promosi akan dapat meningkatkan penjualan. Nilai $\mathrm{R}$ square dalam penelitian ini sebesar 0,321 atau sebesar $32,1 \%$. Hasil penelitian ini mengungkapkan bahwa promosi berpengaruh terhadap keputusan pembelian. Promosi yang diteliti dalam penelitian ini seperti penjualan langsung, hubungan masyarakat, survei perilaku pelanggan, survei perilaku pesaing. Sedangkan survei perilaku pesaing, dan kondisi lingkungan pasar belum dilakukan dalam penelitian ini.

\section{SIMPULAN}

Variabel atribut produk, kualitas produk, promosi secara parsial dan simultan berpengaruh positif dan signifikan. Hal ini berarti bahwa atribut produk perlu lebih diperhatikan dalam meningkatkan keputusan pembelian merek Honda di kota Medan. Dengan harga yang ditawarkan merek Honda yang cukup Tinggi maka perusaahaan sebaiknya lebih meninggkat kan fitur dan desain produknya dan kualitas nya lebih ditingkatkan lagi demikian juga dengan promosi melalui iklan, pameranpameran dan lain-lain lebih ditingkatkan.

\section{REFERENSI}

Aditi, B., \& Hermansyur, H. M. (2017). Pengaruh Kualitas Produk, Citra Merek, Harga dan Promosi Terhadap Keputusan Pembelian Merek Honda
Di Kota Medan. Jurnal Konsep Bisnis dan Manajemen (JKBM), 3(2), 32-43.

Aditi, B. (2017). The Effect Of Atributes Product's Analysis, Halal Certification, And Product Innovation To The Interest Of Consumer BuyingBack Through The Advantage Competitive Of Micro Small And Medium Business (MSMB) In Medan The Effect of Atributes Product's. Journal of Physics Conference, 930(1), 1-6.

Akpoyomare, O. B., Patrick, L. P. K. \& Ganiyu R. A. (2012). The Influence of Product Attributes on Consumer Purchase Decision in the Nigerian Food and Beverages Industry: A Study of Lagos Metropolis. American Journal of Business and Management, 1(4), 196-201.

Anis, L. M., Suharyono., \& Sunarti. (2015). Pengaruh Kualitas Produk terhadap Keputusan Pembelian. Jurnal Administrasi Bisnis (JAB), 28(2), 1-6.

Anuraga, W. (2015). Pengaruh Produk, Harga, Promosi, dan Merk terhadap keputusan pembelian ulang. Jurnal Ilmu dan Riset Manajemen, 4(10), 118.

Ghozali, I. (2011). Aplikasi Analisis Multivariate Dengan Program IBM SPSS 17. Edisi Kelima. Semarang: Badan Penerbit Universitas Diponegoro.

Hair, J. F., Tatham, R. L., Anderson, R. E., \& Black, W., (2007) Multivariate Data Analysis. 5th Edition . Upper Saddle River. New Jersey: Prentice Hall.

Heizer, Jay dan Render. (2012). Manajemen Operasi. Dialih bahasakan oleh Chriswan Sungkono. Edisi Kesembilan. Jakarta; Salemba Empat. Hines, W. H., \& Montgomery, D. C. (1990). Probabilitas dan Statistik dalam Ilmu Rekayasa dan Manajemen. Jakarta: Penerbit Universitas Indonesia. 


\section{Published April 2018 \\ JURNAL ILMIAH MANAJEMEN dan BISNIS \\ ISSN 1693-7619 (print) | ISSN 2580-4170 (online), http://jurnal.umsu.ac.id/index.php/mbisnis}

Khoirotunnisa, A., \& Titis. S. D. (2016). Pengaruh Atribut Produk Terhadap Proses Keputusan Pembelian Konsumen Pada Smartphone Asus. Jurnal Ekonomi Bisnis, 21(1), 28-35.

Kotler, P., \& Armstrong, G. (2007). Prinsip - Prinsip Pemasaran. Edisi 12, Jilid 1. Jakarta: Erlangga.

Kotler, P., \& Amstrong, G. (2008). Manajemen Pemasaran. Edisi Milenium diterjemahkan Benyamin Molan. Jakarta: PT. Prenhallindo.

Kotler, P. \& Keller. (2009). Manajemen Pemasaran . Jilid I. Edisi ke 13. Jakarta: Erlangga.

Kotler, P. Amstrong, G. (2010). Principles Of Marketing. 13 Edition. New Jersey. Upper Saddle River: Pearson Prentice Hall.

Kudo, S. (2013). Harga, Kualitas Produk dan Kualitas Pelayanan Pengaruhnya terhadap Keputusan Pembelian Mobil Toyota Avanza. Jurnal EMBA, 1(3). 1252-1259.

Lubis, A. A. (2015). Pengaruh Harga Dan Kualitas Produk Terhadap Keputusan Pembelian Surat Kabar Pada PT. Suara Barisan Hijau Harian Orbit Medan. Jurnal Ilmiah Manajemen dan Bisnis, 16(2), 1-11.

Modi., Sakshi., \& Jhulka J. (2012). Impact Of Promotional Schemes On Buying Decisions Of A Consumer. International Journal of Sales \& Marketing Management Research and Development, 2 (2), 40-48.

Nasution, M. I., Prayogi, M. A., \& Nasution, S. M. A. (2017). Pengaruh Kualitas Produk, Promosi Terhadap Penjualan Padausaha Mikro Pengrajin Sepatu Di Kecamatan Medan Denai. In Prosiding SNaPP2017Sosial, Ekonomi, dan Humaniora (pp. 6070). Bandung: Universitas Islam Bandung.

Onsu, R., Tawas, T., \& Repi, L. (2015). Atribut Produk, Citra Merek, dan
Strategi Promosi Pengaruhnya Terhadap Keputusan Pembelian Sepeda Motor di Dealer Yamaha Ranotana. Universitas Sam Ratulangi Manado. Jurnal EMBA, 3(2), 818 828.

Priyono, I. (2017). Effect of Quality Products, Services and Brand on Customer Satisfaction at McDonald's. Journal of Global Economics, 5(2), 14.

Rares, A., \& Jorie, R. J. (2015). Pengaruh Harga, Promosi, Lokasi, Citra Merek Dan Kualitas Produk Terhadap Keputusan Pembelian Konsumen Di Toko Bengkel Gaoel Manado Town Square. Jurnal EMAB, 3(2), 592-604.

Subagio, R.A., Suharyono., \& Kusumawati, A. (2015). Pengaruh Atribut Produk Terhadap Keputusan Pembelian (Studi pada Konsumen Produk Low Cost Green Car Astra Daihatsu Ayla di PT. Jolo Abadi, Malang). Jurnal Administrasi Bisnis (JAB), 23(1), 1-9.

Sindi, T. (2013). Atribut Produk, Harga, dan Strategi Promosi Pengaruhnya Terhadap Keputusan Pembelian Konsumen pada Mobil Toyota Vios di PT. Hasjrat Abadi Manado. Jurnal EMBA, 1(4), 1329-1340.

Sugiyono. (2010). Statistika Untuk Penelitian. Bandung: Alfabeta.

Tjiptono, F. (2008). Strategi Pemasaran. Edisi 3. Yogyakarta: Andi.

Walukow, A. L. P., Mananeke, L., \& Sepang, J. (2014). Pengaruh kualitas produk, harga, promosi dan lokasi terhadap keputusan Pembelian konsumen Di Bentenan Center Sonder Minahasa. Jurnal EMBA, 2(3), 17371749.

Widiyatno, B. (2012). Pengaruh Artibut Produk Terhadap Proses Keputusan Pembelian Studi Kasus Konsumen Pada Sentra Industri Jeans di Kecamatan Ulujami Kabupaten 


\section{JURNAL ILMIAH MANAJEMEN dan BISNIS \\ ISSN 1693-7619 (print) | ISSN 2580-4170 (online), http://jurnal.umsu.ac.id/index.php/mbisnis}

Pemalang. Management Analysis

Journal. (MAJ), 1(2).6-10.

Zulkarnaim, T. (2015). Pengaruh Produk,

Promosi Dan Kualitas Pelayanan

Terhadap Keputusan Pembelian

Handphone Samsung Surabaya.

Jurnal Ilmu dan Riset Manajemen,

4(7), 1-22. 